\title{
7. HYDROTHERMAL MANGANESE MINERALS IN LEG 126 CORES ${ }^{1}$
}

\author{
Akira Usui ${ }^{2}$
}

\begin{abstract}
During Ocean Drilling Program Leg 126, which drilled in the forearc and backarc areas of the Izu-Bonin Arc, three substantial manganese deposits were recovered from deep stratigraphic levels. The characteristics of the fossil manganese deposits are similar to those of modern submarine hydrothermal manganese deposits occurring on the seafloor in this area. Two of these manganese deposits-a coating on Pliocene pumice at Site 788 and a fracture infilling in Oligocene volcanic rock at Site 792-are clearly hydrothermal. They have high $\mathrm{Mn} / \mathrm{Fe}$ ratios, lack divalent stabilizing interlayer cations, have large crystal sizes, and have $10 \AA$ $d$-spacings that are resistent to heating. Both of the manganese deposits were presumably deposited near the volcanic front during the initial rifting phases in the backarc and forearc areas. The third deposit consists of manganese minerals in semiconsolidated Miocene claystones at Site 793. This deposit may be the result of primary early-diagenetic manganese deposits that evolved into more stable hydrothermal-like minerals during later diagenesis after burial.
\end{abstract}

\section{INTRODUCTION}

Marine manganese deposits are genetically classified into three categories; hydrogenetic, diagenetic, and hydrothermal. Manganese deposits form nodules, crusts, stains, coating, impregnations, and veinlets on surface sediments and hard rocks in the modern deep-sea environment. Hydrogenetic (precipitated from normal seawater) and diagenetic (precipitated from mildly reduced surface sediments during early diagenesis) manganese deposits are rarely found near island arcs or mid-oceanic ridges, because of the rapid deposition of terrigenous and volcanogenic material. The growth of these two types of deposits requires very slow or no sedimentation in the deep-sea basin or on old seamounts over a long geological time interval (on the order of millions of years). In contrast, recent hydrothermal manganese deposits have been observed only around the volcanically active areas, such as mid-oceanic ridges, backarc spreading centers, and submarine volcanos (Corliss et al., 1978; Lonsdale et al., 1980; Moorby et al., 1984; Usui et al., 1989).

In DSDP/ODP cores, various ancient buried manganese deposits have been described from deposits of most geologic ages younger than the Late Cretaceous (Cronan, 1973; Aumento and MacGillivray, 1975; Glasby, 1978). Previous chemical and mineralogical analyses have shown that the composition of these buried manganese nodules and crusts in the cores are within the range of modern hydrogenetic and diagenetic deposits on the seafloor. Very few hydrothermal manganese deposits, however, have been discovered at deep stratigraphic levels. Hydrothermal manganese deposits generally grow at rates 2 or more orders-of-magnitude faster than abyssal nodules and crusts. The hydrothermal deposits form from low-temperature (presumably $<100^{\circ} \mathrm{C}$ ) hydrothermal solutions circulating through substrate sediments and rocks. Common evidence for fossil hydrothermal manganese deposits primarily consists of the basal metalliferous sediments just above the basaltic rock basement and below the oldest sediments (Dymond et al., 1973; Cronan, 1976; Dymond and Eklund, 1978). Other fossil deposits, which are not basal metalliferous sediments, are described from the Tonga arc region (Hein et al., in press) and the East Pacific (Stoffers et al., 1985).

Because of recent volcanic activity, the Izu-Bonin Arc area does not provide optimal conditions for hydrogenetic or diagenetic depos-

\footnotetext{
'Taylor, B., Fujioka, K., et al., 1992. Proc. ODP, Sci. Results, 126: College Station, TX (Ocean Drilling Program).

${ }^{2}$ Marine Geology Department, Geological Survey of Japan, 1-1-3 Higashi, Tsukuba, Ibaraki 305, Japan.
}

its. Only a record of hydrothermal deposits can be expected in cores from this area. Six black samples that were described as manganese oxides on board Leg 126 were obtained for shore-based analyses. Three out of the six samples contained substantial manganese minerals, and the results of their mineralogical and chemical analyses are presented here (Fig. 1 and Table 1).

\section{METHOD OF ANALYSIS}

Several tens of milligrams of subsamples were carefully separated from sediment chips of the three deposits. Part of the untreated air-dried samples were powdered in acetone and subjected to X-ray diffraction (XRD) analysis. Additional sample splits were analyzed with a Cambridge 360 scanning electron microscope (SEM) and energy dispersive X-ray analyzer (EDX). I conducted XRD analyses on air-dried powders and powders heated at $110^{\circ}$ and $280^{\circ} \mathrm{C}$ for $1 \mathrm{hr}$ to examine mineralogical changes associated with dehydration. The chemical composition was determined quantitatively from ZAFcalibrated digital X-ray spectra data for six points on each sample. In the three samples (OM1, OM2, and OM3; Table 1), only nine elements $(\mathrm{Mn}, \mathrm{Fe}, \mathrm{Si}, \mathrm{Al}, \mathrm{Na}, \mathrm{K}, \mathrm{Ca}, \mathrm{Mg}$, and $\mathrm{Ba}$ ) were detected with EDX during $180 \mathrm{sec}$ of acquisition time. The compositions were calculated assuming full oxidation of all analyzed elements and no water content. The statistical limits of detection for the elements were approximately $0.5 \mathrm{wt} \%$ for $\mathrm{Fe}$ and $\mathrm{Na}, 0.1-0.4 \mathrm{wt} \%$ for $\mathrm{Mg}, 0.05-0.11$ wt $\%$ for $\mathrm{Al}, 0.6-0.8 \mathrm{wt} \%$ for $\mathrm{Cu}$ and $\mathrm{Ni},<0.5 \mathrm{wt} \%$ for $\mathrm{Ca}$, and $<0.3 \mathrm{wt} \%$ for $\mathrm{Si}$ and $\mathrm{K}$.

\section{GEOLOGICAL SETTING}

Drilling during Leg 126 focused on geologic processes associated with recent active arc spreading at the Sumisu Rift and eastern forearc areas (see Taylor, Fujioka, et al., 1990, and Leg 126 Shipboard Scientific Party, 1989a, 1989b, for details). Manganese deposits were found in the cores at Site 788 on the eastern summit of the Sumisu Rift, and at Sites 792 and 793 in the forearc basin areas (Fig. 1). Both the backarc and forearc basins formed by rifting (Taylor, Fujioka, et al., 1990 , pp. 97-126). The Sumisu Rift has been opening since $2 \pm 0.5 \mathrm{Ma}$, following intensive volcanism that began about $5 \mathrm{Ma}$. Based on the benthic foraminifer data, the basement of Site 788 experienced 200$1700 \mathrm{~m}$ of uplift by $275 \mathrm{k} . \mathrm{y}$. During this period of uplift, the upper pumiceous sediments eroded away.

The forearc basin, to the east of the recent volcanic front, formed by mid-Oligocene (28-31 Ma) rifting. Seismic and drilling evidence suggest that a sedimentary basin did not exist in the forearc area before 


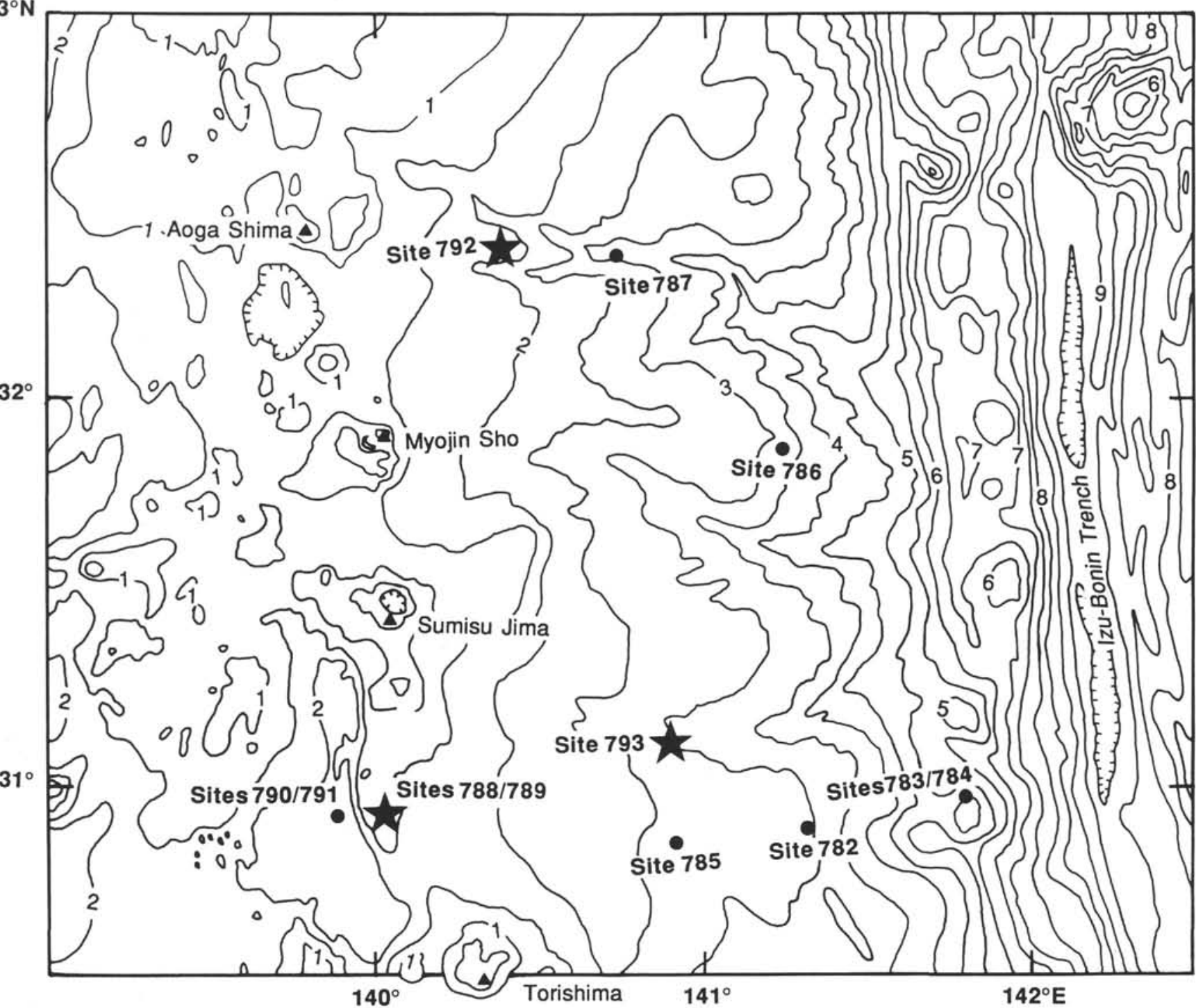

Figure 1. Locations of sites drilled on Legs 125 and 126 with locations of manganese deposits marked by stars. Bathymetric map is from Taylor, Fujioka, et al. (1990, p. 99). Contour interval is $500 \mathrm{~m}$, and depths are in kilometers. The locations of four volcanic islands are marked by small triangles.

$31 \mathrm{Ma}$. After $31 \mathrm{Ma}$, the forearc basin started to form and was rapidly filled by turbidites and debris-flow deposits produced by the concurrent volcanism of the northern volcanos and erosion of the surrounding highs. Sedimentation rates decreased significantly during the Miocene. Sedimentation rates increased again during the Pliocene, a direct result of increased volcanic input.

Extensively altered pore waters were extracted from the volcanogenic sediments at deeper levels of $500 \mathrm{~m}$ below seafloor (mbsf) at Site 792 and below 800 mbsf at Site 793. However, pore-water studies detected no evidence of high-temperature hydrothermal circulation at any Leg 126 sites.

\section{OCCURRENCE OF MANGANESE MINERALS}

The three major deposits of manganese minerals were discovered by the scientific party and are briefly described in the Leg 126 Initial Reports volume (Taylor, Fujioka, et al., 1990). The location and lithostratigraphy of these deposits are summarized below.

\section{Hole 788C (Sumisu Rift Flank)}

Site 788 is located near the top of the eastern flank of the northtrending asymmetric rift. Hydrothermal manganese deposits were discovered in the middle of the wall and on the basin floor during previous shipboard surveys and during submersible observations (Taylor et al., 1990).

The black coating of manganese minerals was identified at one horizon (61.3 mbsf) within the rapidly deposited Pliocene pumice gravel of the Unit I in Hole 788C (Table 1 and Fig. 2). Unit I $(220 \mathrm{~m}$ thick) consists of massive pumice gravels and partly vitric pumiceous sandstone deposited from submarine calderas about 1.2 Ma (Fig. 2). The coating of manganese on pumice gravels generally is $<1 \mathrm{~mm}$ thick. SEM observations revealed that the manganese minerals are well developed in the small cavities on the pumice surface. Single crystals of lath, flake, and petal-like shapes are dominant on a micrometer scale and commonly form aggregates with bumpy and reniform surfaces (Fig. 3). 
Table 1. Location and characteristics of analyzed manganese oxide samples.

\begin{tabular}{|c|c|c|c|}
\hline Sample no. & OM1 & OM2 & OM3 \\
\hline $\begin{array}{l}\text { Hole } \\
\text { Area }\end{array}$ & $\begin{array}{l}788 \mathrm{C} \\
\text { Sumisu Rift }\end{array}$ & ${ }^{792 E}$ & $\begin{array}{l}\text { 793B } \\
\text { Sumisu Jima }\end{array}$ \\
\hline Topography & $\begin{array}{l}\text { East margin of the } \\
\text { rift }\end{array}$ & $\begin{array}{l}\text { Aoga Shima } \\
\text { Canyon } \\
\text { West margin of } \\
\text { forearc basin }\end{array}$ & $\begin{array}{l}\text { Sumisu Jima } \\
\text { Canyon } \\
\text { Center of forearc } \\
\text { basin }\end{array}$ \\
\hline $\begin{array}{l}\text { Latitude (N) } \\
\text { Longitude (E) } \\
\text { Water depth (m) }\end{array}$ & $\begin{array}{l}30^{\circ} 55.36^{\prime} \\
140^{\circ} 00.21^{\prime} \\
1113\end{array}$ & $\begin{array}{l}32^{\circ} 23.96^{\prime} \\
140^{\circ} 22.79^{\prime} \\
1787\end{array}$ & $\begin{array}{l}31^{\circ} 06.33^{\prime} \\
140^{\circ} 53.27^{\prime} \\
2964\end{array}$ \\
\hline $\begin{array}{l}\text { Core, section } \\
\text { Interval }(\mathrm{cm})\end{array}$ & $\begin{array}{l}7 \mathrm{H}-3 \\
15-23\end{array}$ & $\begin{array}{l}68 \mathrm{R}-2 \\
107-109\end{array}$ & $\begin{array}{l}17 \mathrm{R}-2 \\
62-64\end{array}$ \\
\hline Depth (mbsf) & 61.3 & 783.4 & 740.6 \\
\hline Host lithology & $\begin{array}{l}\text { Pumice gravel and } \\
\text { vitric sand }\end{array}$ & $\begin{array}{l}\text { Altered volcanic } \\
\text { sandstone }\end{array}$ & $\begin{array}{l}\text { Nannofossil-rich } \\
\text { claystone }\end{array}$ \\
\hline Occurrence & $\begin{array}{l}\text { Thin coating on } \\
\text { gravels }\end{array}$ & $\begin{array}{l}\text { Matrix or fracture } \\
\text { filling }\end{array}$ & $\begin{array}{l}\text { Stains and } \\
\text { aggregates in } \\
\text { claystone }\end{array}$ \\
\hline Age & $\begin{array}{l}\text { Pliocene } \\
2.4-3.5 \mathrm{Ma}\end{array}$ & $\begin{array}{l}\text { late Oligocene } \\
29 \mathrm{Ma} \text { or } \\
\text { older }\end{array}$ & $\begin{array}{r}\text { early Miocene } \\
22-24 \mathrm{Ma}\end{array}$ \\
\hline Notes & $\begin{array}{l}\text { Contemporary } \\
\text { with rifting }\end{array}$ & $\begin{array}{l}\text { Mn oxide along a } \\
\text { fault }\end{array}$ & $\begin{array}{r}\text { Slow hemipelagic } \\
\text { sedimentation }\end{array}$ \\
\hline
\end{tabular}

\section{Hole 792E (Forearc Basin)}

The manganese deposits at Hole 792E are located near the boundary of Units IV and V. The black manganese deposit forms the matrix of volcanic conglomerate or sandstone in the small fault zone. Unit IV is composed of upper Oligocene sandy mudstone, sandstone, and nannofossil-rich claystone, and Unit V is composed of altered volcanic sandstone and claystone of unknown age. Unit $\mathrm{V}$ is underlain by basement andesitic rock at 804 mbsf. The strong alteration of the volcanic material is indicated by the common occurrence of zeolites and gypsum and by the composition of pore waters (Fujioka et al., 1989; Taylor, Fujioka, et al., 1990, pp. 221-314).

In places, the manganese minerals cement clastic grains and commonly coat them completely. Each crystal is lath, needle, or flakelike shaped, and several micrometers long. The texture of the deposit suggests that manganese minerals filled the spaces in the rocks during water circulation.

\section{Hole 793B (Forearc Basin)}

The stains and irregular aggregates of manganese minerals are distributed throughout several tens of centimeters in the 740.6741.3 mbsf, nannofossil-rich, semiconsolidated claystone of Unit IV (735.7-759.0 mbsf) at Hole 793B. The unit was deposited during the lower Miocene age by slow hemipelagic sedimentation.

Preliminary sedimentological study suggests that during the deposition of Unit IV the forearc was volcanically quiescent, although some volcanogenic material was supplied from the volcanic arc to the west. Evidence of strong alteration of volcanic material is again indicated by common alteration minerals and anomalous interstitial water composition below 800 mbsf in Unit V (Oligocene sandstone and claystone). The alteration zone commonly includes many veins of gypsum and zeolites in the units below Unit V (Fujioka et al., 1989; Taylor, Fujioka, et al., 1990, pp. 315-403).

In the claystone, the stains and aggregates of manganese minerals are arranged in one horizontal plane. Their appearance is similar to that of small manganese nodules (up to a few millimeters) or aggregates of micronodules in pelagic sediments. However, the size of each manganate crystal (several micrometers in length) is significantly larger than diagenetic or hydrogenetic manganese minerals, which are usually on the order of $10 \mathrm{~nm}$ (Burns and Burns, 1977).

\section{MINERALOGY AND CHEMISTRY}

The manganese deposits described above are characteristic of the large manganate crystals that form lath, plate, needle, or bladelike shapes in the samples. Their maximum length is on the order of several micrometers, and they are $<1 \mu \mathrm{m}$ in thickness. The size and shape of these crystals resemble those of recent marine hydrothermal manganese minerals and ancient hydrothermal manganese deposits on land, rather than diagenetic or hydrogenetic minerals.

The mineralogy of the manganese minerals is an important piece of data that is necessary in determining the origin and depositional processes of manganese deposits. Vernadite, a disordered iron-manganese mineral, is a hydrogenetic mineral that commonly forms crusts and nodules on seamounts (Ostwald, 1984). It has a mixed-layer structure with only two diffuse XRD lines at $d=2.4 \AA$ and $1.4 \AA$. On the other hand, the iron-free $10 \AA$ manganates, todorokite and buserite, are common both in diagenetic and hydrothermal manganese deposits. Recent investigations of the marine $10 \AA$ manganates divide the minerals into two series: the buserite and the todorokite series. The former is a sheet $10 \AA$ manganate that can be stabilized by interlayer hydrated cations $\left(\mathrm{Ni}^{2+}, \mathrm{Cu}^{2+}\right.$, and $\left.\mathrm{Zn}^{2+}\right)$, typical of diagenetic, high-grade nodules on the abyssal floor. In this article, I refer to $\mathrm{Ni}-, \mathrm{Cu}-$, or $\mathrm{Zn}$-rich buserite simply as buserite. The unsaturated sheet manganate with stabilizing interlayer cations can contract to $7 \AA$ manganate in the air. Todorokite is a tunnel-structured manganate stabilized by walls of manganate octahedrons with variable dimensions (Arrhenius and Tsai, 1981; Bish and Post, 1989; Usui et al., 1989).

Chemical analysis and the contraction-expansion tests in the XRD analyses (see Paterson, 1981; Arrhenius and Tsai, 1981) are necessary to discriminate todorokite and buserite. Some todorokites are heatresistant above $100^{\circ} \mathrm{C}$, even up to $400^{\circ} \mathrm{C}$ (Miura and Hariya, 1984). However, buserite contracts at $100^{\circ} \mathrm{C}$ or less. Heating the mineral does not always produce unambiguous results in case the todorokite has a larger dimension (Chukhrov et al., 1976) and may also contract to $7 \AA$ (Usui et al., 1989). Chemical analysis must be used in conjunction with heating tests.

Samples OM1, OM2, and OM3 were examined with XRD and EDX and by thermal gravimetric analysis (TGA). The XRD patterns for air-dried, $110^{\circ} \mathrm{C}$-dried, and $280^{\circ} \mathrm{C}$-dried samples are shown in Figure 4 and the EDX analyses in Table 2 . None of the three samples contains detectable $\mathrm{Ni}, \mathrm{Cu}$, or $\mathrm{Zn}$. The sum of the three elements may not exceed $1 \%$ (Table 2). Their chemical composition does not indicate the presence of stabilizing cations in buserite. In turn, $\mathrm{Ba}$, and possibly $\mathrm{Ca}$, concentrations are higher than the buserite- or vernadite-rich marine manganese deposits. The results of heating the samples at $110^{\circ} \mathrm{C}$ shows that the $10 \AA d$-spacing decreases slightly but does not collapse to $7 \AA$. These results, together with the chemical composition data, indicate a hydrothermal origin for OM1, OM2, and OM3.

The TGA results reveal that the loss of water at $100^{\circ} \mathrm{C}$ for $\mathrm{OM} 2$ is only $7.0 \mathrm{wt} \%$ (Fig. 5). The compositions (Table 2) and correlation plots (Fig. 6) show that the samples are nearly pure manganates containing alkali and alkali-earth elements. Some linear dependency of minor elements on $\mathrm{Si}$, typically for $\mathrm{Mg}$, indicates contamination from ambient silicate particles. Only Ba is negatively correlated with $\mathrm{Si}$. An attempt to extrapolate the linear dependency suggests that $\mathrm{Ba}$ and possibly $\mathrm{Ca}$ are essential elements in the manganese phase wheras $\mathrm{Mg}$ is not. Both types of todorokites from land-based hydrothermal manganese mines and the manganate deposits studied are clearly enriched in $\mathrm{Ba}$ and $\mathrm{Ca}$ in comparison with abyssal nodules (Haynes, 1986; Ebihara and Usui, unpubl. data, 1988). 

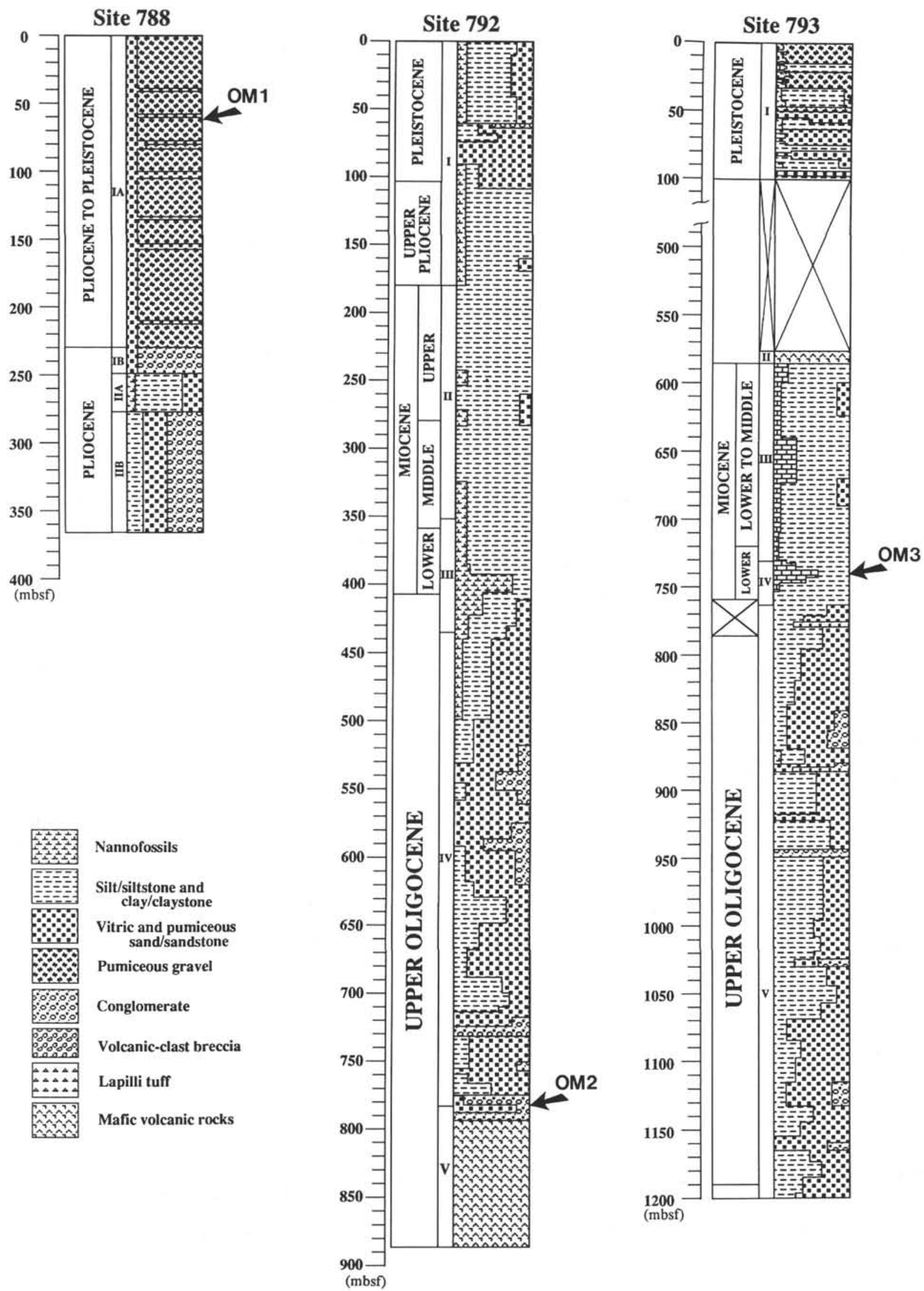

Figure 2. Graphic lithology of Sites 788, 792, and 793 with the location of manganese deposits indicated by arrows. Original illustration is from Taylor, Fujioka, et al. (1990). 
Table 2. Chemical composition of manganese minerals determined by EDX (wt \%).

\begin{tabular}{|c|c|c|c|c|c|c|c|c|c|}
\hline Samples & Mn & $\mathrm{Fe}$ & $\mathrm{Na}$ & K & $\mathrm{Ca}$ & $\mathbf{M g}$ & $\mathrm{Ba}$ & $\mathrm{Si}$ & Al \\
\hline \multicolumn{10}{|l|}{ This study: } \\
\hline OM1 \#1 & 55.4 & 1.13 & "20.23 & 0.81 & 0.60 & 1.53 & 1.26 & 1.37 & 0.46 \\
\hline \#2 & 49.9 & 1.40 & 1.27 & 0.87 & 0.65 & 3.11 & 1.74 & 2.49 & 1.15 \\
\hline$\# 3$ & 49.2 & ${ }^{\mathrm{a}} 0.87$ & 0.50 & 1.16 & 0.69 & 4.39 & 1.43 & 2.41 & 1.58 \\
\hline \#4 & 53.8 & 2.58 & ${ }^{20} 0.26$ & 0.70 & 0.53 & 1.35 & 0.97 & 1.86 & 0.68 \\
\hline \#5 & 59.9 & 0.99 & ${ }^{2} 0.13$ & 0.54 & 0.49 & 0.07 & 0.88 & 0.20 & ${ }^{\mathrm{a}} 10.05$ \\
\hline \#6 & 50.7 & 1.62 & 0.26 & 0.83 & 1.02 & 2.88 & 0.77 & 2.38 & 1.59 \\
\hline Average & 53.1 & 1.43 & 0.44 & 0.82 & 0.66 & 1.33 & 1.18 & 1.78 & 0.92 \\
\hline OM2\#1 & 24.4 & 7.25 & 0.37 & 0.40 & 2.09 & 2.11 & 0.73 & 16.69 & 2.72 \\
\hline \#2 & 55.9 & 0.83 & ${ }^{2} 0.10$ & 0.47 & 1.14 & 0.39 & 1.73 & 1.59 & 0.19 \\
\hline \#3 & 52.7 & 0.58 & 0.80 & 0.57 & 1.29 & 1.50 & 1.84 & 2.40 & 0.33 \\
\hline \#4 & 47.6 & 1.38 & ${ }^{2} 0.14$ & 0.59 & 1.66 & 1.11 & 1.87 & 5.47 & 1.09 \\
\hline \#5 & 53.8 & 0.99 & 0.34 & 0.41 & 1.42 & 0.72 & 2.26 & 2.11 & 0.27 \\
\hline \#6 & 54.8 & 3.78 & ${ }^{20} 0.09$ & 0.34 & 1.23 & ${ }^{2} 0.04$ & 1.42 & 0.60 & ${ }^{2} 0.030$ \\
\hline${ }^{\mathrm{b}}$ Average & 53.0 & 1.51 & 0.29 & 0.48 & 1.35 & 0.75 & 1.97 & 2.43 & 0.38 \\
\hline OM3\#1 & 52.0 & 2.10 & ${ }^{\mathrm{a}} 0.19$ & 0.36 & 7.71 & ${ }^{\mathrm{a}} 0.08$ & 1.37 & 0.11 & 0.20 \\
\hline$\# 2$ & 54.0 & 2.81 & ${ }^{\mathrm{a}} 0.21$ & 0.47 & 4.25 & ${ }^{\mathrm{a}} 0.09$ & 1.49 & 0.14 & 0.35 \\
\hline$\# 3$ & 44.5 & 1.34 & 1.08 & 0.98 & 1.51 & 1.74 & 1.57 & 2.19 & 6.38 \\
\hline$\# 4$ & 42.6 & 0.61 & 1.10 & 0.77 & 2.16 & 1.67 & 1.61 & 2.53 & 7.70 \\
\hline \#5 & 36.9 & 2.66 & 1.31 & 1.15 & 4.19 & 1.69 & 0.80 & 3.11 & 8.74 \\
\hline$\# 6$ & 48.4 & 1.87 & ${ }^{2} 0.25$ & 0.83 & 3.18 & 0.79 & 0.97 & 1.27 & 4.40 \\
\hline Average & 46.4 & 1.88 & 0.68 & 0.76 & 3.83 & 1.01 & 1.30 & 4.63 & 1.56 \\
\hline \multicolumn{10}{|l|}{${ }^{c}$ Pacific nodules: } \\
\hline & $16-27$ & $6-17$ & $1.3-2.3$ & $0.3-0.9$ & $0.5-3.0$ & $0.8-1.8$ & $0.14-0.34$ & $2-8$ & $0.3-2.0$ \\
\hline \multicolumn{10}{|l|}{${ }^{\mathrm{d}}$ Todorokite on land: } \\
\hline Todoroki & 48.9 & 1.14 & 0.10 & 0.57 & 2.18 & 0.48 & 2.80 & NA & 0.04 \\
\hline Ikeshiro & 48.3 & 0.15 & 0.81 & 0.84 & 1.18 & 1.61 & 0.80 & NA & 0.38 \\
\hline Fukaura & 51.4 & 0.03 & 0.68 & 1.25 & 0.38 & 1.56 & 1.14 & NA & 0.09 \\
\hline
\end{tabular}

Note: $\mathrm{NA}=$ not analyzed.

${ }^{\text {a }}$ Less than statistical error ( 2 standard deviations).

${ }^{\mathrm{b}}$ Excluding OM\#1.

${ }^{c}$ Haynes et al. (1986).

M. Ebihara and A. Usui (unpubl. data, 1988).

Further structural analyses would provide another constraint, although these mineralogical and chemical characteristic strongly indicate their hydrothermal origin.

\section{DEPOSITIONAL ENVIRONMENT}

The results of this study suggest that the three manganese deposits studied are hydrothermal in origin. The large size and chemical composition of the single crystals of manganates are typical of marine hydrothermal manganese deposits (Stoffers et al., 1985; Usui et al., 1986). The resistance of the $10 \AA d$-spacing to dehydration and the very low concentrations of $\mathrm{Ni}, \mathrm{Cu}$, and $\mathrm{Zn}$ support the same origin; the strong separation of manganese from iron through hydrothermal processes and from a rapid supply of manganese from solution.

The geological history at Sites 788 and 792 suggests that Samples $\mathrm{OM} 1$ and $\mathrm{OM} 2$ formed on or close to the then-active submarine volcanos on the volcanic front, similar to the modern low-temperature hydrothermal manganese deposits on the submarine volcanoes along the Izu-Bonin and Mariana arcs (Usui et al., 1986, 1989; Hein et al., 1987).

In contrast, the sediments coexisting with Sample OM3 suggest a hemipelagic depositional environment for Sample OM3. These conditions seem to suggest a hydrogenetic or diagenetic origin rather than a hydrothermal origin for OM3, although the mineralogical and chemical features indicate a hydrothermal origin. One probable interpretation is that $\mathrm{OM} 3$ was originally deposited as diagenetic buserite in small nodules or micronodules within oxidized hemipelagic surface sediments before it was covered and buried by subsequent sedimentation. The buserite was then transformed into more stable todorokite (tunnel-structured) at higher temperatures during later, more intensive, diagenesis of the unconsolidated sediments.

The anomalously high $\mathrm{Ca} / \mathrm{Mg}$ ratio of some EDX analyses on OM3 (Table 2) are consistent with similar high $\mathrm{Ca} / \mathrm{Mg}$ ratios of interstitial waters of the basement volcanogenic sediments and suggests strong alteration after burial.

\section{CONCLUSIONS}

In the Izu-Bonin Arc area, present and past geological conditions are not optimal for the deposition of hydrogenetic or diagenetic manganese minerals. Hydrothermal manganese deposits have been the dominant manganese deposits, as recorded in the Leg 126 cores analyzed in this study. The characteristics of the buried manganese deposits are similar to those of modern hydrothermal manganese deposits on the seafloor around submarine volcanos and rifts in this area.

The two manganese deposits (i.e., a coating on Pliocene pumice at Site 788 and a fracture filling in the Oligocene volcanic rock at Site 792) are clearly hydrothermal, with a high $\mathrm{Mn} / \mathrm{Fe}$ ratio, a lack of divalent stabilizing interlayer cations, a large crystal size, and resistivity to structural collapse during heating. Both of these manganese deposits were presumably deposited near the volcanic front during the initial stage of opening of rifts in the backarc and forearc areas.

The manganese minerals in the Miocene semiconsolidated claystone at Site 793 are compositionally hydrothermal, although they may have been deposited in hemipelagic sediment on the basin floor. The primary early-diagenetic manganese deposits may have changed into a more stable hydrothermal-like mineral during low-temperature, late-stage diagenesis of sediments.

\section{ACKNOWLEDGMENTS}

The author acknowledges A. Nishimura of the Geological Survey of Japan for helpful discussions, information, and on-board descriptions of samples. K. Fujioka, Ocean Research Institute, University of Tokyo, kindly provided this opportunity and encouraged this study. 


\section{OM1}

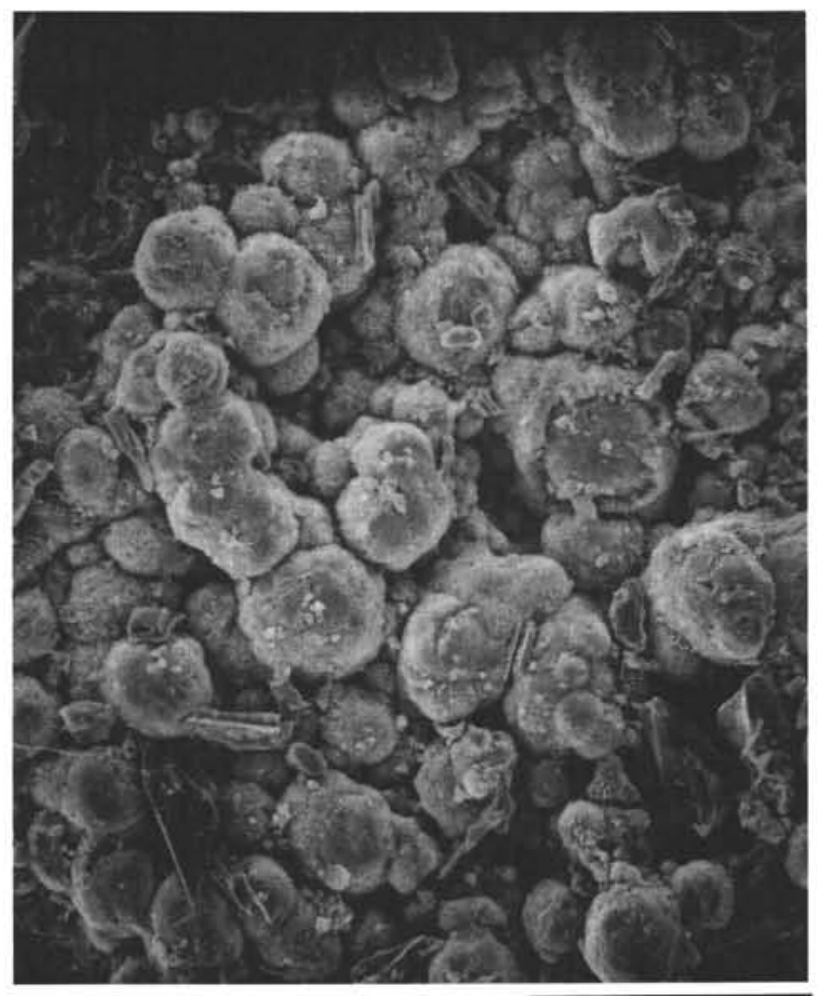

$200 \mu \mathrm{m}$

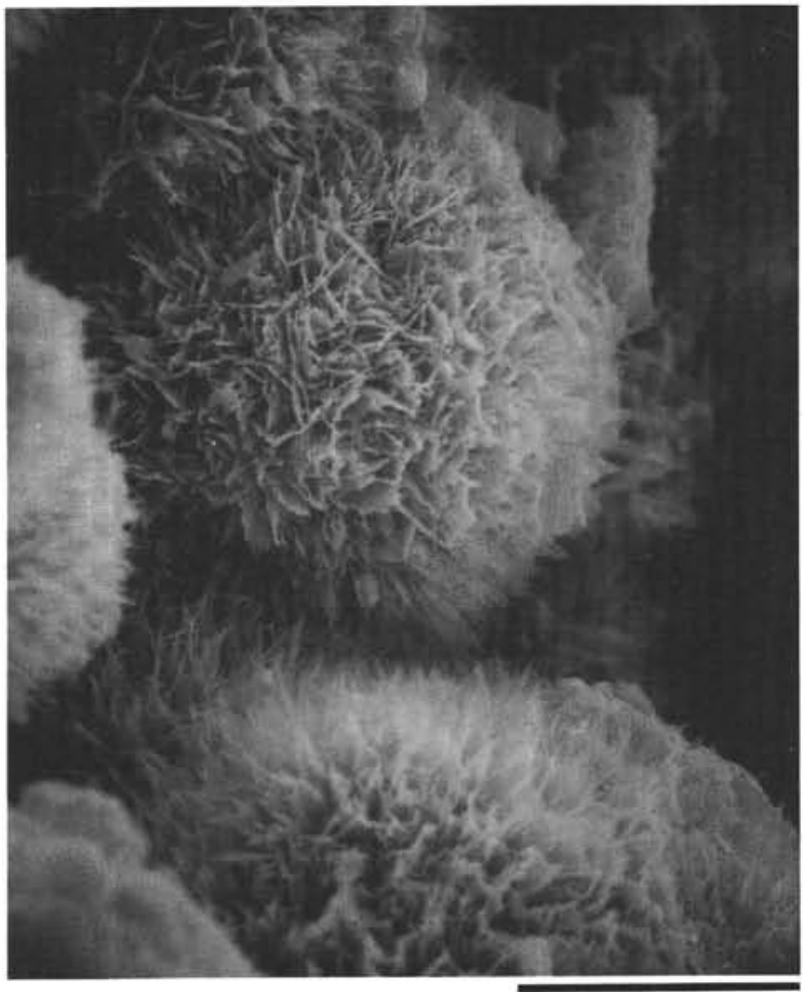

$20 \mu \mathrm{m}$

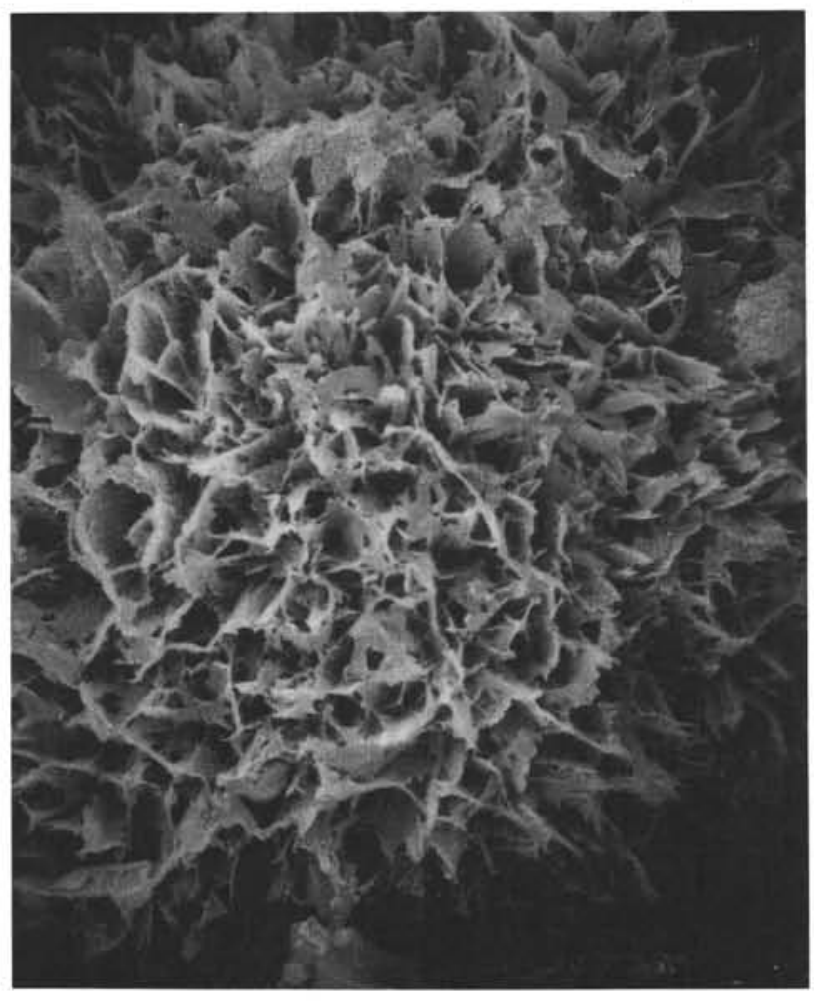

$10 \mu \mathrm{m}$

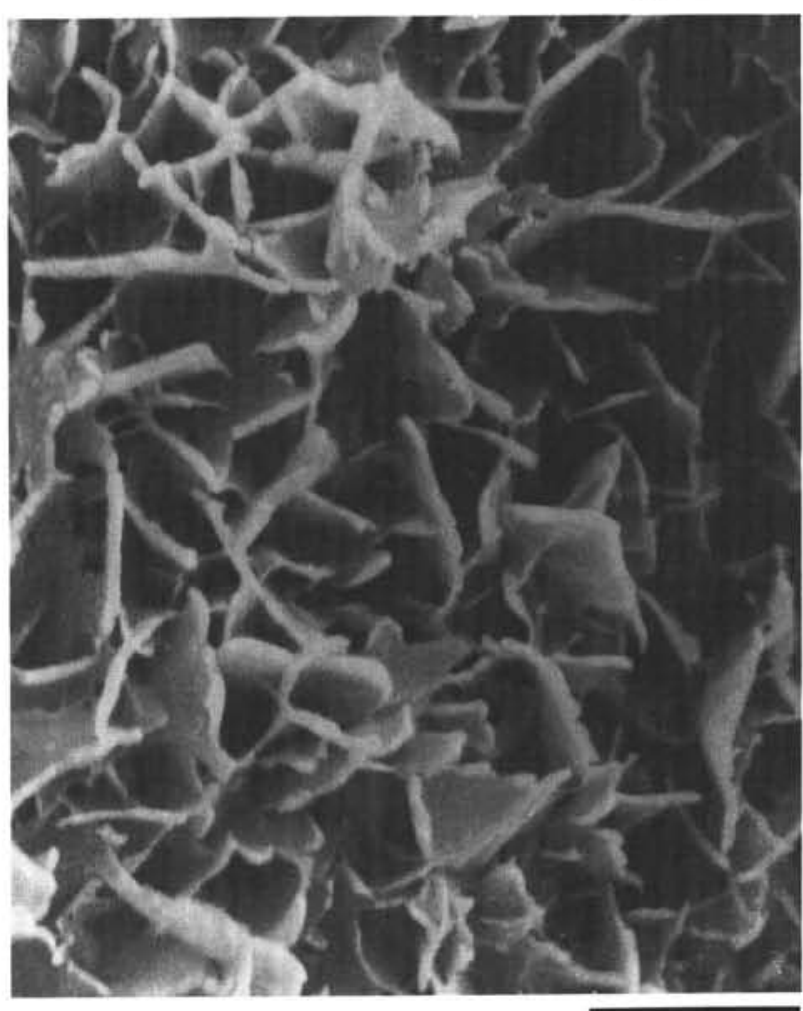

$2 \mu \mathrm{m}$

Figure 3. Scanning electron micrographs of various morphologies of todorokites. A. Upper left: globular surface of Sample OM1, with reniform surfaces forming in places; other photos: close-ups of the globular surface showing aggregation of plate and bladelike flakes producing a boxwork structure. B. Upper left: dense layers of Sample OM2; other photos: close-ups of broken surfaces showing bundles of blades and needles of single crystals. C. Upper two photos: bladelike single crystals of Sample OM2; lower two photos: poorly developed single crystals of Sample OM3. 


\section{OM 2}

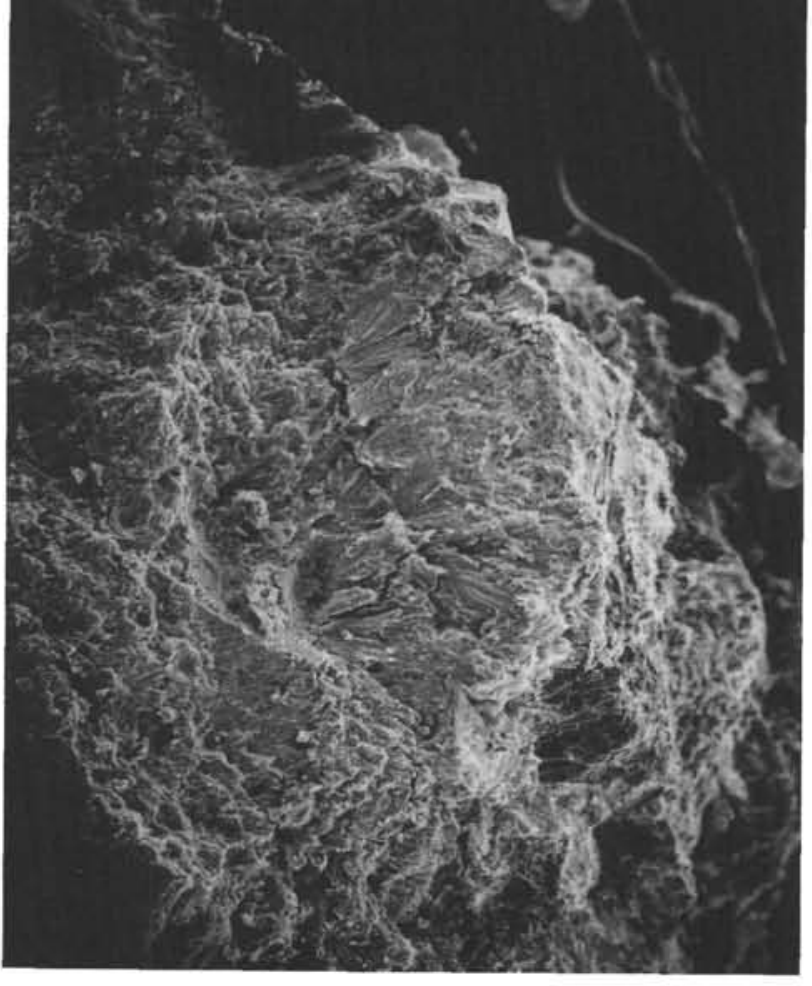

$1 \mathrm{~mm}$

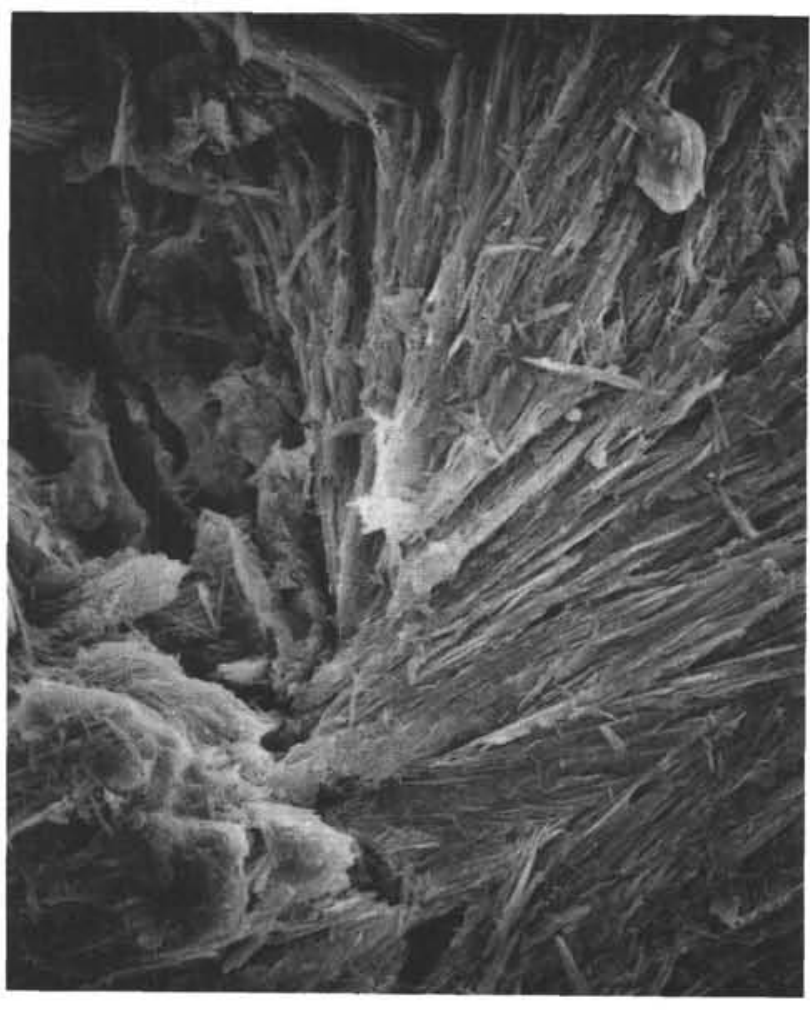

$50 \mu \mathrm{m}$

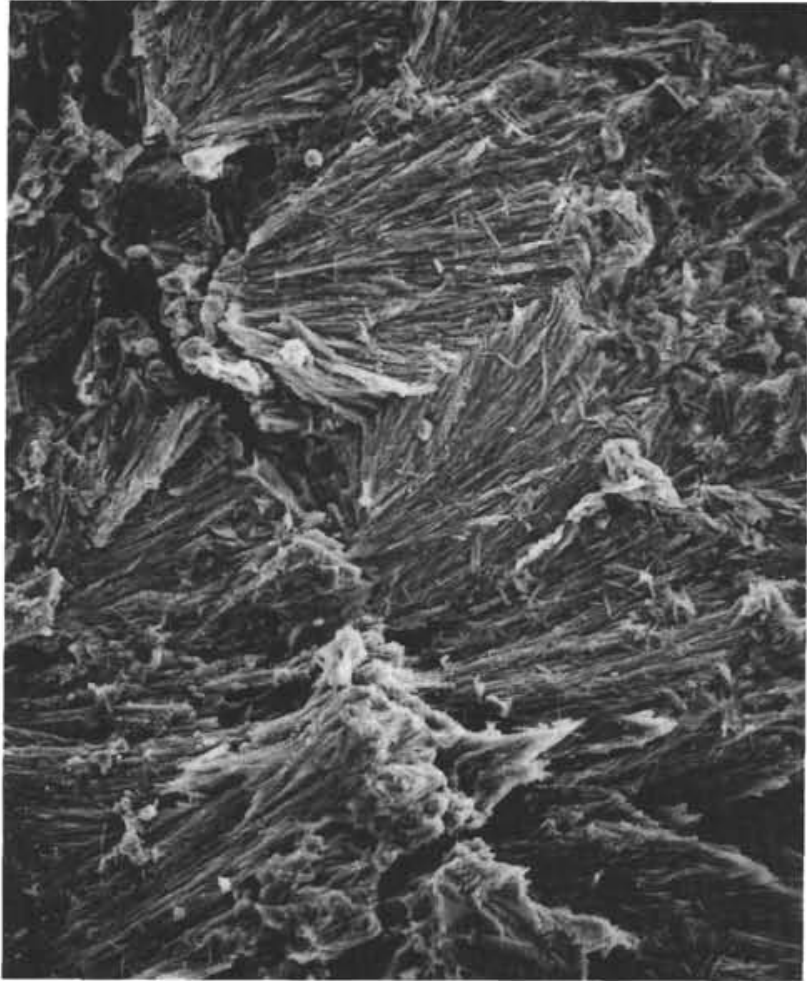

$100 \mu \mathrm{m}$

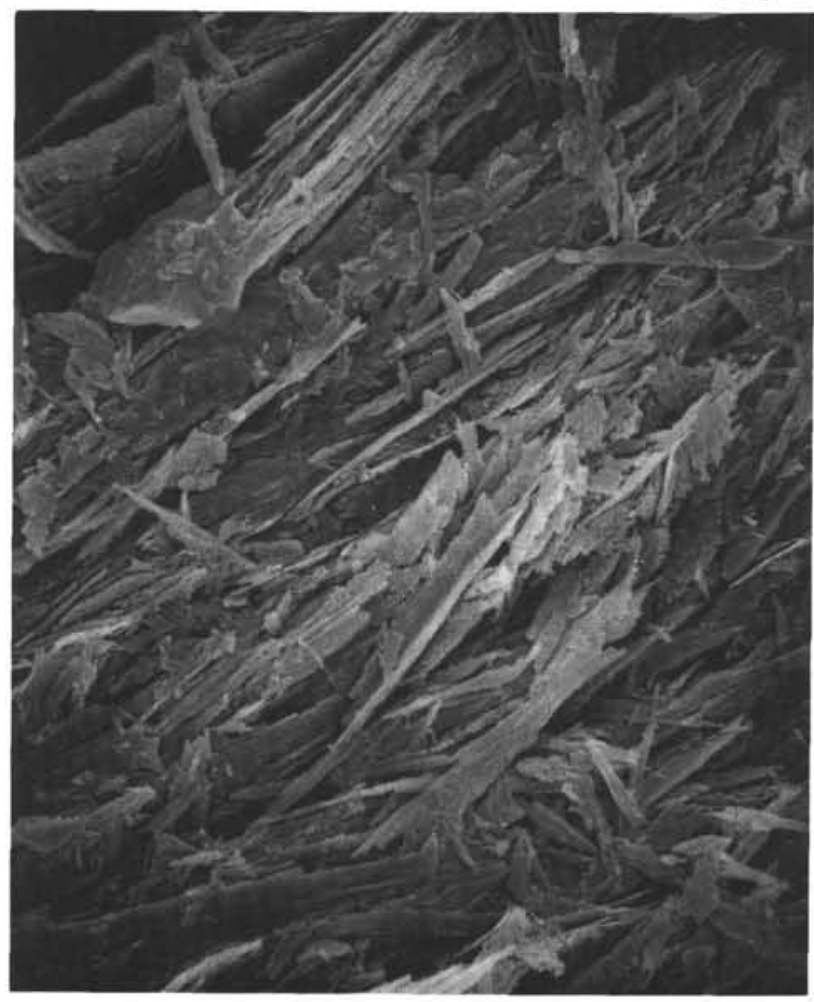

$10 \mu \mathrm{m}$

Figure 3 (continued). 
c

OM 2

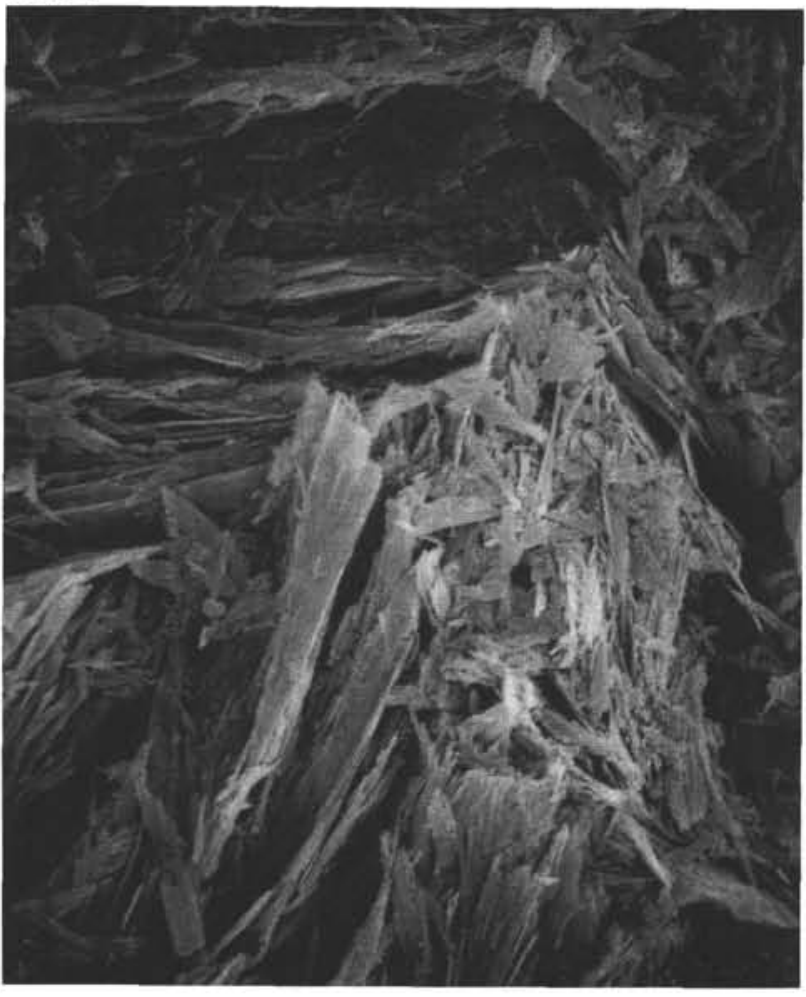

\section{OM 3}

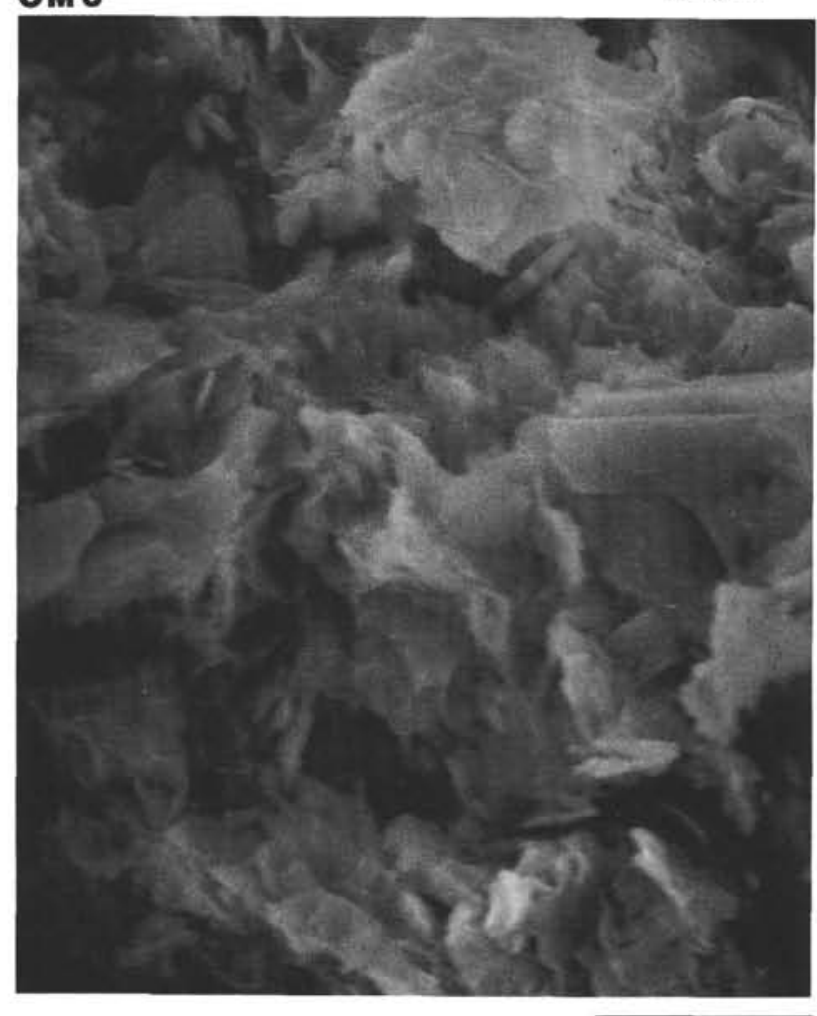

$10 \mu \mathrm{m}$

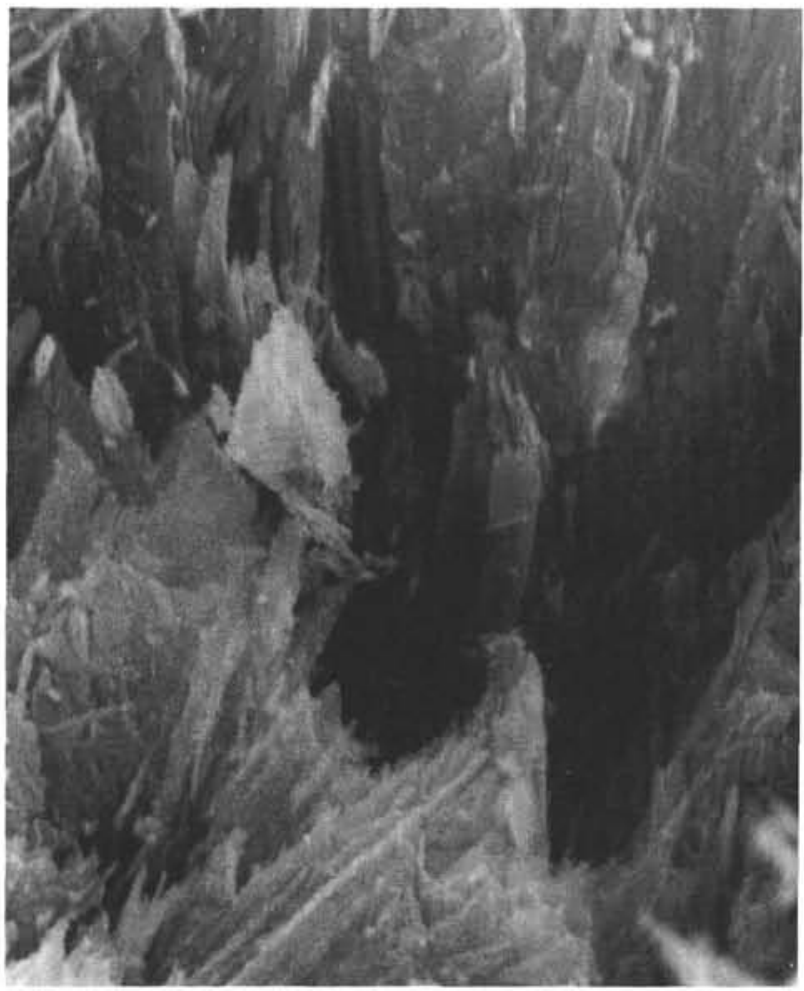

$10 \mu \mathrm{m}$

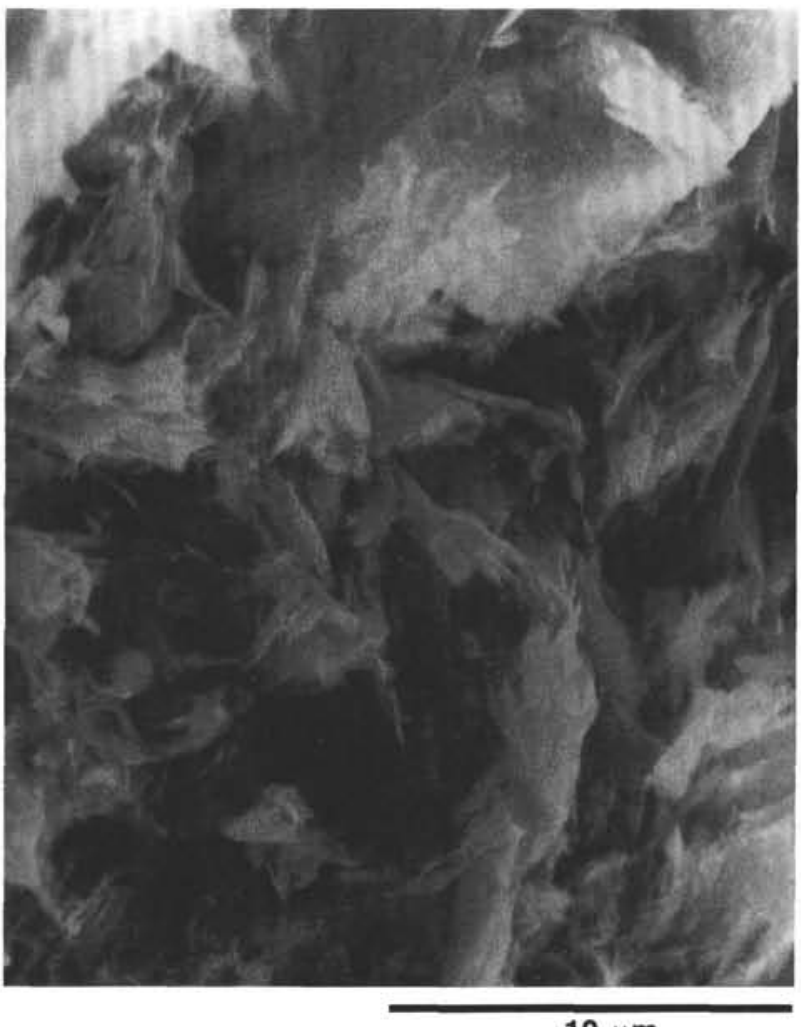

$10 \mu \mathrm{m}$

Figure 3 (continued). 

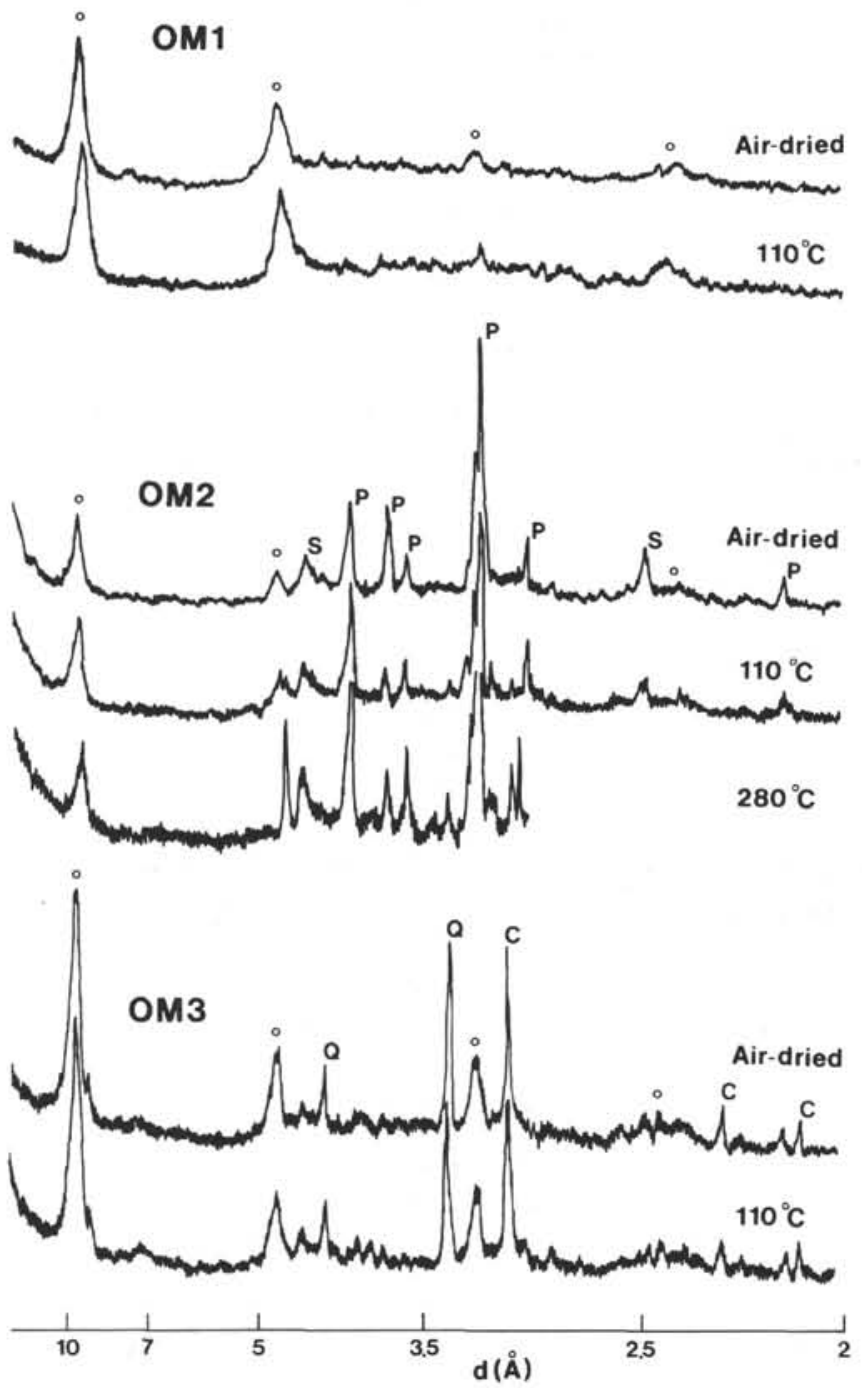

Figure 4. X-ray powder diffraction patterns of manganate samples. The small open circles and the letters $\mathrm{P}, \mathrm{Q}, \mathrm{C}$, and S denote peaks of $10 \AA$ manganate, plagioclase, quartz, calcite, and smectite, respectively. All three samples are resistant to collapse on heating to $110^{\circ} \mathrm{C}$ for $2 \mathrm{hr}$. Sample OM2 remains as a $10 \AA$ manganate even on heating to $280^{\circ} \mathrm{C}$. The heat-resistant nature suggests that the manganese mineral is tunnel-structured todorokite.

G. Arrhenius, W. Paplawsky, and B. Gedulin, Scripps Institution of Oceanography, are also acknowledged for fruitful discussions and encouragement during this study.

\section{REFERENCES}

Arrhenius, G., and Tsai, A. G., 1981. Structure, phase transformation and prebiotic catalysis in marine manganate minerals. SIO Ref. Ser., 81:1-19.

Aumento, F., and MacGillivray, J. M., 1975. Geochemistry of buried Miocene-Pleistocene ferromanganese nodules from the Antarctic Ocean. In Hayes, D. E., Frakes, L. A., Init. Repts. DSDP, 28: Washington (U. S. Govt. Printing Office), 795-803.

Bish, D., and Post, J. E., 1989. Thermal behavior of complex, tunnel-structure manganese oxides. Am. Mineral., 74:177-186.

Burns, R. G., and Burns, V. M., 1977. Mineralogy. In Glasby, G. P. (Ed.), Marine Manganese Deposits: Amsterdam (Elsevier), 185-248.

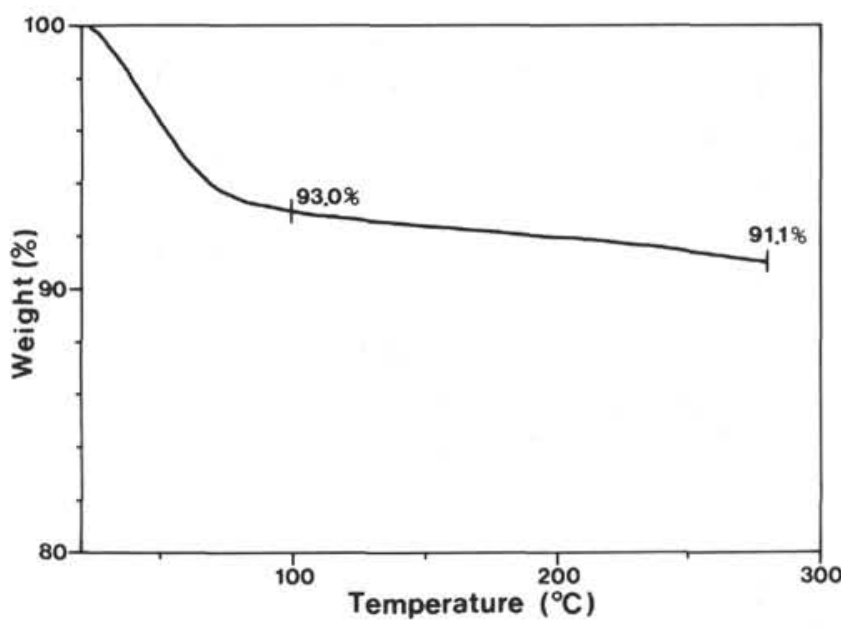

Figure 5. Thermal gravity analysis of Sample OM2. The curve shows no significant release of interlayer water molecules over $100^{\circ} \mathrm{C}$. The loss of weight at $100^{\circ} \mathrm{C}$ is insignificant. There is no structural change during heating (see Fig. 4).

Chukhrov, G. V., Zvyagin, B. B., Yermilova, L. P., and Gorshkov, A. J., 1976. Mineralogical criteria in the origin of marine iron-manganese nodules. Mineral. Dep., 11:24-32.

Corliss, J. B., Lyle, M., Dymond, J., and Crane, K., 1978. The chemistry of hydrothermal mounds near the Galapagos rift. Earth Planet. Sci. Lett., 40:12-24. Cronan, D. S., 1973. Manganese nodules in sediments cored during Leg 16, Deep Sea Drilling Project. In van Andel, T. H., Heath, G. R., Init. Repts. DSDP, 16: Washington (U.S. Govt. Printing Office), 605-608.

1976. Basal metalliferous sediemts from the eastern Pacific. Geol. Soc. Am. Bull., 87:928-934.

Dymond, J., Corliss, J. B., Field, C. W., Dasch, E. J., and Veeh, H. H., 1973. Origin of basal metalliferous sediments from the Pacific Ocean. Geol. Soc. Am. Bull., 84:3355-3372.

Dymond, J., and Eklund, W., 1978. A microprobe study of metalliferous sediment components. Earth Planet. Sci. Lett., 40:243-251.

Fujioka, K., Taylor, B., Nishimura, A., Koyama, M., Kaiho, K., Tazaki, K., Janecek, T., and Scientific Party of ODP Leg 126, 1989. Drilling across the Bonin Arc-results of ODP Leg 126 Cruise. Geograph. J. Jpn., 98:54-78.

Glasby, G. P., 1978. Deep-sea manganese nodules in the stratigraphic records: evidence from DSDP cores. 28:51-64.

Haynes, B. W., Law, S. L., and Barron, D. C., 1986. An elemental description of Pacific manganese nodules. Mar. Min., 4:239-276.

Hein, J. R., Fleishman, C. L., Morgenstein, L. A., Bloomer, S. H., and Stern, R. J., 1987. Submarine ferromanganese deposits from the Mariana and Volcano volcanic arcs, West Pacific. Open-File Rep.-U.S. Geol. Surv., No. 87-281:1-9.

Hein, J. R., Schulz, M. S., and Kang, J.-K., in press. Insular and submarine ferromanganese mineralization of the Tonga-Lau region. In Ballance, B. F., Herzer, R. H., and Vallier, T. L. (Eds.), Geology of the Tonga-Lau Regions of the Southwest Pacific. Circum-Pac. Counc. Energy Miner. Resour.

Leg 126 Shipboard Scientific Party, 1989a. Arc volcanism and rifting. Nature, 342:18-20.

, 1989b. ODP Leg drills the Izu-Bonin arc. Geotimes, 34:36-38.

Lonsdale, P., Burns, V. M., and Fisk, M., 1980. Nodules of hydrothermal birnessite in the caldera of a young seamount. J. Geol., 88:611-618.

Miura, H., and Hariya, Y., 1984. Todorokite with long spacing and structure of Manganese dioxide minerals. J. Mineral. Soc. Jpn., 16:301-308.

Moorby, S. A., Cronan, D. S., and Glasby, G. P., 1984. Geochemistry of hydrothermal Mn-oxide deposits from the S.W. Pacific island arc. Geochim. Cosmochim. Acta, 48:433-441.

Ostwald, J., 1984. Ferruginous vernadite in an Indian Ocean ferromanganese nodule. Geol. Mag., 121:483-488.

Paterson, E., 1981. Intercalation of synthetic buserite by dodecylammonium chloride. Am. Mineral., 66:424-427. 

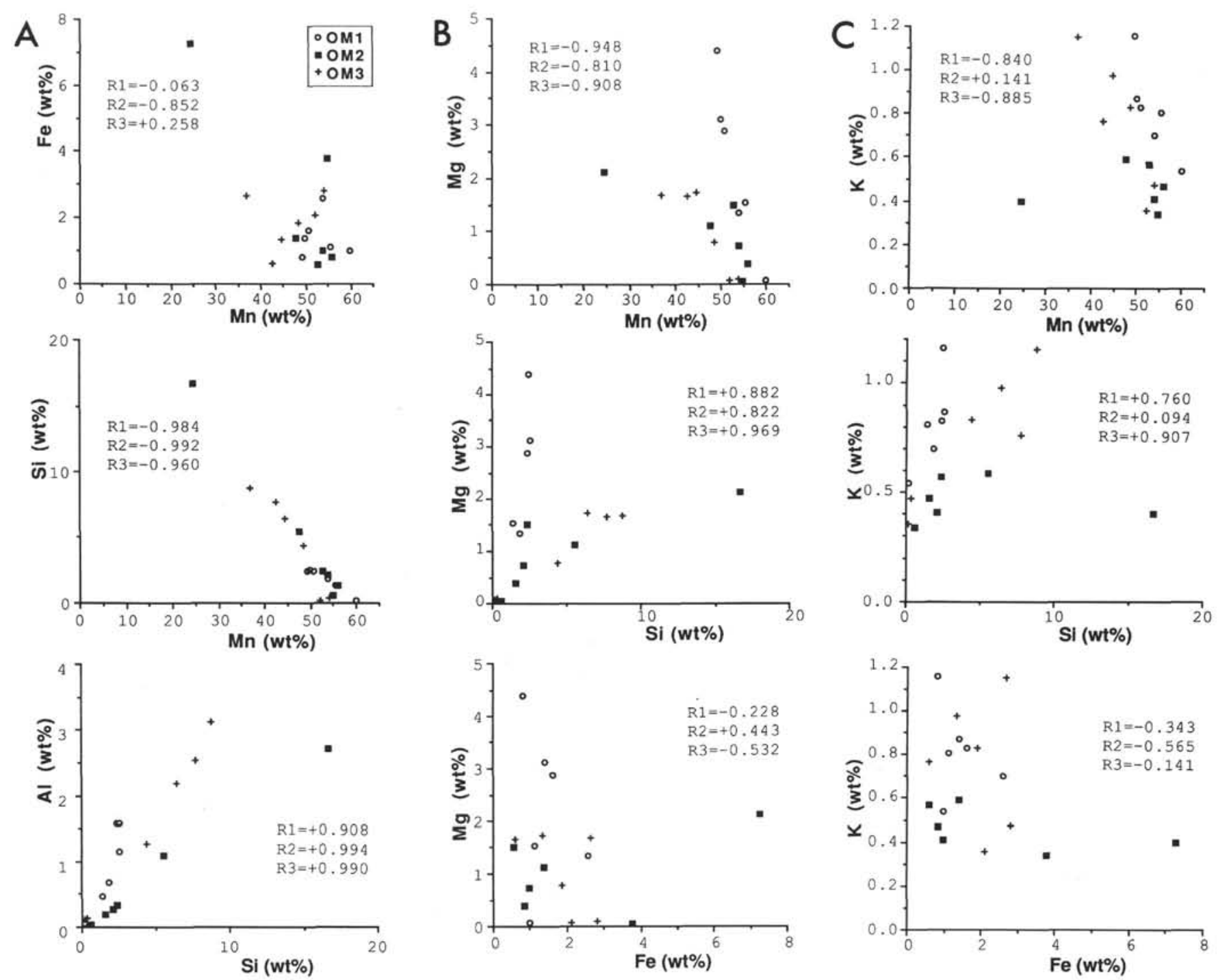

Figure 6. Scatter plots of element concentration, demonstrating dependent and independent variations of minor elements to Mn, Fe, and Si. Coefficients of correlations (R1, R2, and R3) were calculated for each six-data set of Samples OM1, OM2, and OM3, respectively. Weight percent concentrations are listed in Table 2. A. Relationship between $\mathrm{Mn}, \mathrm{Si}$, and $\mathrm{Fe}$. Aluminosilicate minerals dilute manganate components, whereas $\mathrm{Fe}$ concentration varies independently. B-F. Mg, Na, and $\mathrm{K}$ concentrations are correlated with $\mathrm{Si}$ concentration, whereas $\mathrm{Ca}$ and $\mathrm{Ba}$ are correlated with $\mathrm{Mn}$.

Stoffers, P., Lallier-Verges, E., Pluger, W., Schmitz, W., Bonnot-Courtois, C., and Hoffert, M., 1985. A "fossil" hydrothermal deposit in the South Pacific. Mar. Geol., 62:133-151.

Taylor, B., Brown, G., Fryer, P., Gill, J., Hochstaedter, F., Hotta, H., Langmuir, C., Leinen, M., Nishimura, A., and Urabe, T., 1990. ALVIN-SeaBeam studies of the Sumisu Rift, Izu Bonin arc. Earth Planet. Sci. Lett., 100:127-147.

Taylor, B., Fujioka, K., et al., 1990. Proc. ODP, Init. Repts., 126: College Station, TX (Ocean Drilling Program).

Usui, A., Mellin, T. A., Nohara, M., and Yuasa, M., 1989. Structural stability of marine $10 \AA$ manganates from the Ogasawara (Bonin) Arc: implication for low-temperature hydrothermal activity. Mar. Geol., 86:41-56.
Usui, A., Yuasa, M., Yokota, M., Nishimura, A., and Murakami, F., 1986. Submarine hydrothermal manganese deposits from the Ogasawara (Bonin) Arc, off the Japan Islands. Mar. Geol., 73:311-322.

Date of initial receipt: 2 January 1991

Date of acceptance: 17 May 1991

Ms 126B-122 

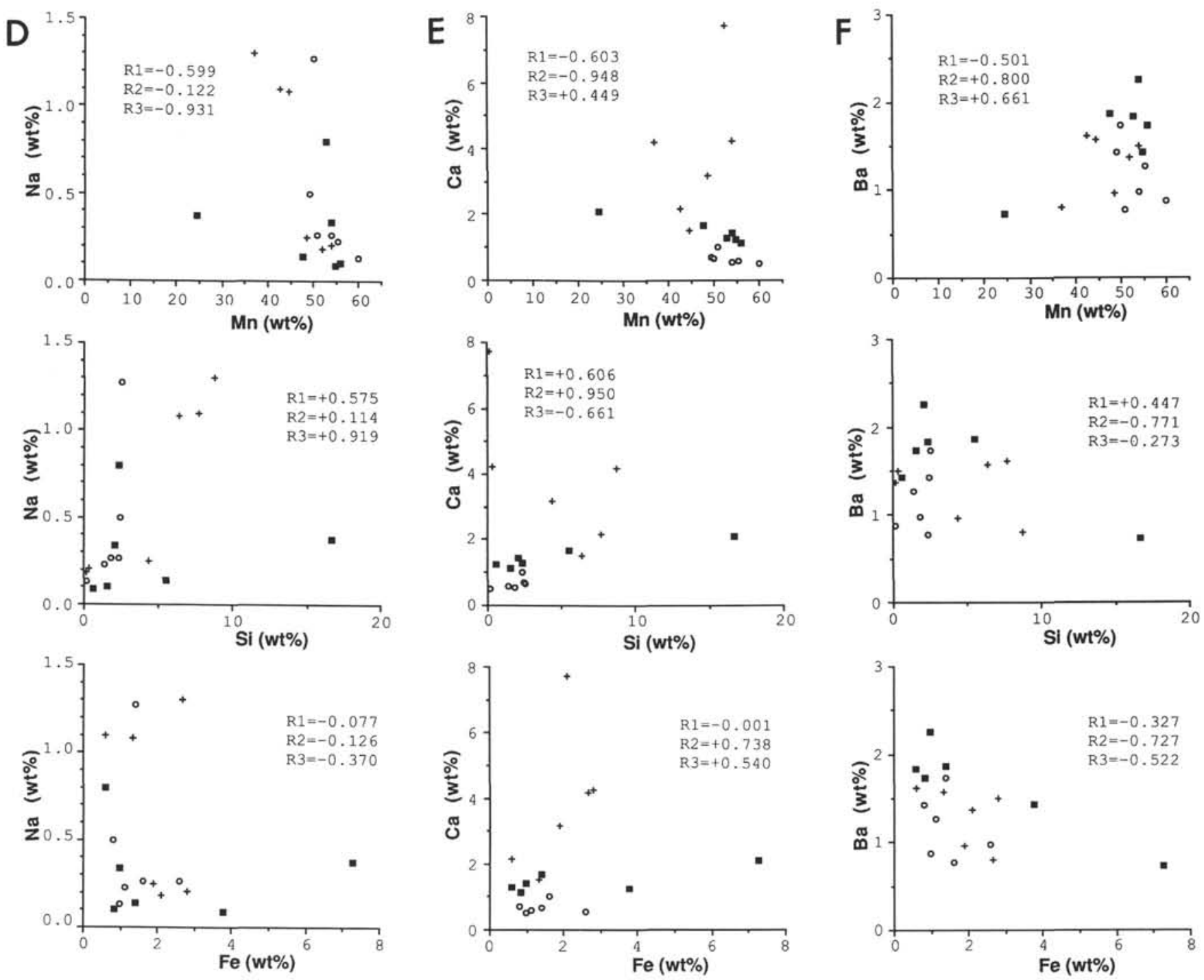

Figure 6 (continued). 